\title{
Discourse on Time and Religion
}

\author{
Wenbo Zhu
}

New York University, The USA

\begin{abstract}
:
Wandering through time, one might wonder how time transforms our understanding of religion in a historical context. Time is scientifically illustrated as the fourth dimension of space, which is irreversible but gradually transforms our lives in a quiet manner. More importantly, religious beliefs have also been constantly challenged by customs, traditions, new values, and perspectives over the course of time. These challenges are symbolized by particular philosophers such as Saint Augustine, Rene Descartes, Giambattista Vico, and etc. In the thought of different philosophers, the role of the time guide us to understand religion and the world from the ancient period of 350 A.D. to the modern period of 1800 A.D.
\end{abstract}

Keywords—Paradigm Shifts, Temporal Measure, Metaphysical Dualism, Object validity. 


\section{I.INTRODUCTION}

od and Nature are inseparable during the ancient period because people used their religious

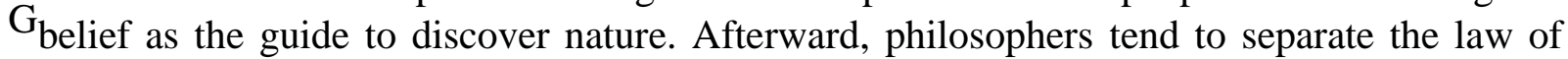
nature from the divine interventions to discover object validity during the modern period. Transcendence represents God's nature beyond our limited understanding and imagination, which opposed the idea of immanence that God is manifested in the material world. It is important to know that God transforms our understanding of nature in a historical context, and the idea of transcendence functioned as a lighthouse in the enlightenment, which facilitates the discovery of time and truth in different historical backgrounds.

During the ancient time period from 3000 B.C. to A.D. 500, God is symbolized as powerful existence and supremely good, the source of everything, which represents all the universal knowledge in the world. Ancient people viewed nature as the representation and symbolization of God, and religious rituals are performed during irregular natural phenomena such as tornado, earthquakes, and volcanic eruptions; People would characterize these phenomena as the casual relationship that God is angry, and those natural disasters are because people do not obey God's instructions. Moreover, People attempt to discover nature because they want to learn and pray to God in a better way. People in ancient times would think that God is immanence because they believe there is divine intervention in the material world. Philosophers such as Aristotle claim that God is the final cause of all things. Therefore, Aristotelian philosophy isthe most representative thinking for people in this era because people agree to associate everything in their daily life with God's plan. If Aristotle creates a general model, the so-called "theory of everything", that can even explain the nature of the smallest substance in the world, God must be the cause of everything that explains changes and motions of things.

\section{SubJectivity And ObJect VAlidity}

\section{A. Enlightenment Period}

During the enlightenment period from 17 century to 18 century, the modernized view of natural law was developed, and the interpretation of biblical scripture was against by philosophers such as Descartes and Rousseau. Philosophers in the Enlightenment period agree upon not using biblical scripture to interfere with the discussion of scientific knowledge and objective truth. The prophetic tradition was banished in this period, and the idea of immanence is overthrown by the idea of natural laws based on transcendence. Moral value and intrinsic value are essential to all people, and human rights are protected by God and nature. 


\section{B. Object Validity}

Descartes begins with subjectivity, trying to discover object validity, which gives three approves that God does not mislead us away from object validity and perfect objectivity. Firstly, Descartes defined the relationship between God and nature as deterministic causal relationships in which cause is bigger than effect, and the universe obeys the laws of nature. Secondly, we are free from divine intervention. Therefore, we could not understand God through nature, which challenges the ancient view of God and nature. Thirdly, reason is what God gives us, and thus we can make sense of the world. Thus, it is within our ability to understand nature using reason rather than relying on the biblical account of nature. Since Descartes rejects all the knowledge from the past, his cartesian skepticism and subjectivity apply to modern philosophy. The transcendental nature of the world separates God from scientific discovery and natural rights explorations. The idea of natural and universal law has emerged after the thirty years war, and people were defended by those laws. Descartes' philosophical understanding of God and nature pushes the development of natural and universal laws. It further supports the advocation of human rights that only appears after World War II.

In Husserl's philosophy, his view of historicism reflects on the presence and the past. Critical and subjective individuals are defined as "Lebenswelt life-world"-- a self-evident experienced world. Husserl's phenomenology develops an objective view of subjective intentionality, and his phenomenology was later subverted by Heidegger. The historical subject is the humans that do not break away from the world, and our understanding of subjectivity projects our future in the ontological condition. In Husserl's passage, he noticed the "crisis of European existence" is "in countless symptoms of a corrupted life, is no obscure fate, no impenetrable destiny", which argues for the pursuit of rationality and subjectivity for humanity [4]. Life is a cycle that does not escape to a linear timeline that endeavors the predetermined future. 


\section{Theoretical foundations of natural laws}

Rousseau wonders from the theoretical foundations of human nature to the revolutionized development of government and hierarchies while separating God's influence on the discovery of natural laws. Transcendence is a lighthouse that moves us away from the focus of divine interventions while pursuing objective knowledge. Rousseau identifies and analyzes the natural law using his own methodology. The interpretation of natural laws was controlled by the church and priest in ancient times, and the relationship between God and nature is inseparable. Therefore, Rousseau proposed the concept of natural and social inequality, which distinguishes man from nature, and these characteristics depend on the concept of freedom, perfectibility, and the knowledge of death. The prophet interpreted by the priest channels to the outside world during the medieval age, and the transcendence means that there are an objective and eternal time and truth. Rousseau against the biblical account of nature, and he believes that discard the authority of biblical scripture might be a better solution to explore the nature of people. God transforms our understanding of nature in a historical context, which requires time as an important factor. Since we understand that we are free from divine intervention, nature is more observable for us. The development of civil rights and social equality should be similar to historical progress, which needs time and truth in the long run.

\section{PARADIGM SHIFTS}

Time and space give us the opportunity and capacity to think and apply paradigm shifts on religion in the one-dimensional timeline. When the priest and the church speak in the name of God and refute the previous heliocentric model, pioneers, such as Martin Luther and Galileo Galilei, bring the reformation to the monopoly of the catholic church and prove that the earth revolves around the sun using telescope and pendulum. Similar paradigm shifts require philosophers such as Augustine, Descartes, and Vico to push philosophical thinking to a higher level, therefore dives deeper into their understanding of time and religion would provide us with more insight from their specific historical background.

\section{TEMPORAL MEASURE}

We, humans, as mortal beings, can only understand time as a timeline that has beginning and end in a temporal measure, but Augustine presents a different concept that we are all in a world where the elapsed time does not exist. To better understand Augustine's philosophy, we need to dive deep into the image of God at first. In Augustine's Confessions, Augustine starts to develop philosophical thinking about the image of God. Augustine believes that God is powerful and omnipresent, and he refutes the idea of Manichee dualism where good power and evil power coexist. However, he could not figure out why God allows the nature of evil to exist in the world. The existence of God gives Augustine a perception that God is a myth that hides from the public and exists above us; therefore, Augustine discovers that God is inherently good and evil is only a corruption of humanity. 
After constructing the image of God, Augustine describes what God did before and after the creation of the world, which is that God spiritually created the world in a sense that we cannot understand. At this unique fixed point in the timeline, nothing begins or ends, but the concept of time gives people a misconception about our experience in terms of past and future. Our fabrication of the concept of time is simply to help us understand time. He stretches our understanding of time to a higher level where our souls are linked in eternal time, and our mortal body only lives within the temporal frame. According to Book XI in Confession, Contrary to the fact that we are living in temporal spaces, "Your years are but a day, and your day is not recurrent, but always today...Y Your today is eternity", God is living in eternity[1]. Moreover, the divine God would not care for the temporal measure of time that we are focusing on, and God would not care for the successive events in the timeline. Although the detachment of God is real and painful, the perception of time and truth gives us the capacity of memory as an instrument to understand the world. For example, If we have no measurement to calculate time, we are unable to perceive time through the lens or filter God gave us to understand the world. Augustine's philosophy reflects on how God's existence impacts our views on time and eternity, and he states that we are trapped in time compared to God. Rather than staying in the pain of detachment with God, we ought to focus on our present moments. Through lenses, the exploration of time and truth can give us a better understanding of the world around us.

Dasein's historicity derided from the temporal measure of time and existential finitude understanding of the world. Humans are limited beings and unable to think infinity in terms of finitude because we often use reason and the transcendental form of math and physics to look into the knowledge of our existence from the history of time. Being is the basis of truth, and the realm of history just as the tool of language, transforms human agencies that human can be the master of their self.

Kant and the frankfurt school uphold human science and history relativism, people need to understand each period of history in order to understand the totality of history and there is no objective truth for the interpretation of the history. Kant's philosophy combines rationalism and empiricism, which emphasizes the capacity to have absolute knowledge and truth in the nature of things. In his article, our inner subjective sense, "provide any intuition of the soul itself as an object", which represents our subjective time and history [5]. Since he believes in the immortality of the soul, he would reject the idea that being-towards-death makes our life meaningful. Kant would agree with the idea of Dasein and being in time as a spiritual pursuit, and he would argue on the moral law and rational faith to analyze the being and presence of Dasein in subjectivity. 


\section{HISTORICAL PERSPECTIVE}

\section{A. Prime Mover}

Time is viewed as a temporal medium that separates us from God in Augustine's philosophy; nevertheless, Descartes proposes a new interpretation of time as a tool to foster our reason and logic in the 17th century. Our exploration of religion also has an effect on grasping the nature of time. In Discourse on Method, Descartes gives three points of agreement, "All our ideas..must have some foundation in the truth, for...God... would not have put them in us without that", that is, God will not mislead us away from the time and truth [2]. First, God makes us live in a world that obeys the laws of nature and logic, which demonstrates the deterministic causal relationship of the concept that cause is bigger than the effect in a timeline. Second, Descartes presumes that there is a prime mover, who freed us from divine intervention, thus we can obey the laws of math. Third, reason and logic are what God gives us, thus we can make sense of the world. Descartes' principle and laws are based on the cartesian time that is intrinsic and successive; the cause and effect happen in a successive timeline. In metaphysical dualism, time exists as a source of knowledge that is neither material nor non-material; it is object validity that guides our reasoning and exists both in mind and matter. The application of reason requires time, and therefore we can rationally justify the religion by knowing the truth.

\section{B. Political History}

Time pushes the philosophical thinking of religion from a political history perspective in Vico's philosophy. In the structure of history, historical progress is achieved by each stage. At the first stage, our belief system is merely based on the outside interpretation of God controlled by the priest in the period of ancient history before 500 A.D. This poetical stage lacks rationality, which is not found in natural law or universal law. At the second stage, people would become more aware of the context where Martin Luther's independent interpretation of God emerges. During this stage, it is a period called the Middle Ages from 500-1500 A.D. People no longer believe in Church and priest, and truth becomes context-dependent, the idea of providence presented as God's plan for humanity in this semi-divine stage. At the third stage, people start to make rational decisions based on reason and logic, creating equal frameworks for political or religious institutions in the Modern Age after 1500 A.D. People like Giambattista Vico starts to challenge the enlightenment idea and found historicism and constructivism where new science is combined with rational philosophies and past history. As time flies, our history is where we can learn and adapt, "The necessity, both human and doctrinal, that the origins of this Science be derived from sacred history", is essential for the search of objective validity [3]. In the new science, we are all defended by natural and universal law that advocates the idea of human rights, which bring the reconstruction of truth in our culture and history in context. As a philosopher, people such as Vico are detached from his historical time of 17-18 century. The detachment from the current time is essential for philosophers to explore or invent innovative ideas. Since we are trapped in the current time, Vico's The First New Science tends to settle us with the "ideal eternal history" that social and political beliefs and practices a slow and steady historical progress. 


\section{HISTORICITY}

Dilthey believes history is science, and people need to understand the whole structure of history by contextualizing and using hermeneutics. Dilthey would disagree with Heidegger's theory of being because he believes that we can only gain knowledge from all of history rather than subjective introspection. However, Dilthey would agree that temporality is an important concept in historicity. There is unique truth to each particular historical period, thus we need to contextualize temporality and use hermeneutics to analyze it. While Heidegger believes history can subjectively help us to understand being and existence, Dilthey argues, "Preserve the general validity of interpretation against .... skeptical subjectivity, and ..give a theoretical justification for such validity", which supports historical disciplines and methodology for human studies [6].

Heidegger reflects on historicity to elaborates on Dasein and it is an important guide to lead our understanding of subjectivity. According to the Temporality and Historicity section in the Being and Time, western philosophy misleads us in a way that subject and object are not deeply connected in the relationship of being. It has resulted in the forgetting of our being, and the notion of being reminds us of the meaning of our existence. The subjectivist framework has allowed our reason to dominate in the period of enlightenment, and our notion of critique and the notion of pure reason has enabled us to explore the knowledge of the world. However, we forgot our way of existence in the modern world. The metaphysical reflection of the subjectivity ideas pushes the development of historicity and ontological ideas. Humans, as finite and temporal entities, should focus more on subjective activity and self-consciousness..

\section{CONCLUSION}

In conclusion, while we are on the path of discovering God, we also explored the beauty of natural laws. Although people often struggle with the existence of God and nature, people would reflect on reasoning to achieve objective validity, and also history will make us understand the true nature of the world. Truth, as the function of time, along with our limited reasoning, embraced the idea of transcendence to establish new philosophies independently in the historical context. Time does not exist from God's perspective because God lives in eternity while we are mortal human beings that can only construct the concept of "time" to understand the world in Augustine's philosophy. Therefore, we should appreciate the ability to measure time for understanding religion and the world. Descartes gives us hope that time not only exists but also fosters reason and logic in the historical context so that we can learn all the physical properties of the world through time. Vico pushes the definition of time to a higher place where time has taken effect in religious and political behaviors, and time is paralleling or connecting the truth on a historical scale. The role of time, just as a lens, transforms our understanding of religion and the world by fostering our reason and logic, and it has also taken effect in religious and political behaviors to achieve object validity with historical progress. 


\section{ACKNOWLEDGMENT}

I would like to express my gratitude to every single author of the reference, this work is impossible to complete without your previous efforts. This article was completed under the guidance of Professor Aner Barzilay. I appreciate the guidance in western history and philosophy from Professor Barzilay and Tutor Emily, which broad my selection of content and writing specifications. At the same time, I thank Tutor Emily for supervising me and providing instructions on the paper. At last, I would like to thank again everyone who has helped me with the paper, and your assistance has made this work possible and valuable.

\section{REFERENCES}

[1] Augustine on the topic of time. (n.d.). Retrieved March 15, 2021, from http://web.mnstate.edu/gracyk/courses/web\%20publishing/AugustineBookXI.htm

[2] Descartes, R., \& Veitch, J. (1953). A discourse on method. London: Dent.

[3] Vico, G., \& Pompa, L. (2003). The first new science. Beijing: Zhongguo zheng fa da xue chu ban she.

[4] Husserl, E. (1965). Phenomenology and the crisis of philosophy. Philosophy as rigorous science ; and, Philosophy and the crisis of European man. New York: Harper \& Row.

[5] Kant, I., \& Smith, N. K. (2003). Critique of pure reason. Houndmills, Basingstoke, Hampshire: Palgrave Macmillan.

[6] Husserl, E. (1965). Phenomenology and the crisis of philosophy. Philosophy as rigorous science ; and, Philosophy and the crisis of European man. New York: Harper \& Row. 